\title{
SOSIALISASI PENCEGAHAN DAN PENGADAAN SAPRAS PENCEGAHAN COVID 19 DI KECAMATAN KEMILING KOTA BANDAR LAMPUNG
}

\section{SOSIALIZATION OF PREVENTION AND PROCUREMENT OF COVID 19 PREVENTION AND INFRASTRUCTURE IN KECAMATAN KEMILING KOTA BANDAR LAMPUNG}

\author{
Novita Sari ${ }^{1 *}$, M. Saputra ${ }^{2)}$, Aswin $^{3)}$, Avitha $P^{4)}$, Mega $C^{5)}$ \\ ${ }^{1)}$ Fakultas Ekonomi dan Bisnis, Institut Informatika dan Bisnis Darmajaya, Bandar Lampung \\ email: novi_a2g@darmajaya.ac.id \\ ${ }^{2)}$ Fakultas Ekonomi dan Bisnis, Institut Informatika dan Bisnis Darmajaya, Bandar Lampung \\ email: saputra@darmajaya.ac.id \\ ${ }^{3)}$ Fakultas Ekonomi dan Bisnis, Institut Informatika dan Bisnis Darmajaya, Bandar Lampung. \\ email: aswin@darmajaya.ac.id \\ ${ }^{4)}$ Fakultas Ekonomi dan Bisnis, Institut Informatika dan Bisnis Darmajaya, Bandar Lampung \\ email: avitha_p@darmajaya.ac.id \\ ${ }^{5)}$ Fakultas Ekonomi dan Bisnis, Institut Informatika dan Bisnis Darmajaya, Bandar Lampung \\ email: mega_clauri@darmajaya.ac.id
}

\begin{abstract}
ABSTRAK
Covid-19 merupakan penyakit pernapasan akut yang disebabkan oleh virus corona jenis baru. Penyakit ini pertama kali merebak di Wuhan, Cina lalu menyebar hampir ke seluruh dunia dan menyebabkan pandemi global. Penyakit ini menyerang semua golongan, dewasa, lansia, maupun anak-anak. Semua lapisan masyarakat dari mulai dewasa hingga anak-anak perlu mendapatkan edukasi yang mudah dipahami mengenai Covid19 dan cara-cara pencegahannya. Hal ini yang menjadi dasar dilaksanakannya praktek kerja pengabdian masyarakat IIB Darmajaya. Tujuan kegiatan ini adalah untuk ikut aktif dalam upaya pencegahan virus Covid-19 dengan memberikan sosialisasi tentang Covid-19 dan upaya pencegahannya melalui pembagian APD dan juga pembagian tempat cuci tangan kepada masyarakat Kelurahan Pinang Jaya, Kecamatan Kemiling, Kota Bandar Lampung. Kegiatan ini dilakukan bermitra dengan masyarakat Kelurahan Pinang Jaya . metode yang dipergunakan adalah dengan cara penyuluhan dan sosialisasi tentang pencegahan Covid19, pengadaan sarana prasarana pencegahan Covid 19. Hasil dari pengabdian ini adalah masyarakat dapat memahami lebih jauh mengenai virus Covid 19 ini sehingga masyarakat dapat turut serta melakukan upaya pencegahan penularan Covid-19 dimulai dari diri mereka masing-masing.
\end{abstract}

Kata Kunci: Pengabdian, Covid-19, Pandemik, Sosialisasi, Edukasi

\section{ABSTRACT}

Covid-19 is an acute respiratory disease caused by a new type of corona virus. This disease first broke out in Wuhan, China then spread almost throughout the world and caused a global pandemic. This disease attacks all groups, adults, the elderly, and children. All levels of society from adults to children need to get education that is easy to understand about Covid19 and ways to prevent it. This is the basis for implementing IIB Darmajaya community service work practices. The purpose of this activity is to actively participate in efforts to prevent the Covid-19 virus by providing socialization about Covid-19 and prevention efforts through the distribution of PPE and also the distribution of hand washing facilities to the people of Pinang Jaya Village, Kemiling District, Bandar Lampung City. This activity is carried out in partnership with the people of Pinang Jaya Village. The method used is by means of counseling and socialization about the prevention of Covid-19, the provision of infrastructure for preventing Covid-19. of themselves.

Keywords: Community Service, Covid-19, Pandemic, Socialization, Education 


\section{PENDAHULUAN}

Kecamatan Kemiling adalah salah satu kecamatan di Kota Bandar Lampung Provinsi Lampung. Kecamatan ini terletakdi daerah perbatasan antara Kota Bandar Lampung dengan Kabupaten Pesawaran. Posisi yang sangat strategis ini membuat Kemiling tumbuh sebagai salah satu Kecamatan ramai penduduk di kota Bandar Lampung.Kecamatan Kemiling terdiri fari 9 desa atau kelurahan dengan luas wilayah 12.700 ha . Kecamatan kemilig didominasi oleh lingkungan perumahan ramai penduduk. Sehingga fasilitas untuk masyarakat tumbuh dan berkembang.Seperti pasar, sekolah dari jenjang usia dini hingga jenjang menengah atas, dua universitas besar, pertokoan, pusat hiburan, daln lain sebagainya. Masyarakat yang tinggal didominasi oleh profesi buruh, pedagang, petani, wiraswasta, karyawan swasta, dan Aparatur Sipil Negara (ASN).

Dengan jumlah penduduk sebanyak 65.637 jiwa dan kepadatan penduduk 2.708 jiwa maka dkhawatirkan di masa pandemic Covid 19 ini , merebaknya virus tidak dapat dikendalikan. Di tambah lagi, Kemiling berbatasan langsung dengan Kabupaten Pringsewu dan kabupaten lainnya sehingga makin mengkhawatirkan terpapar virus jika tidak segera dilakukan upaya-upaya sosialisasi pencegahan dan pengadaan sarana prasarana untuk mencegah merebaknya Covid-19) (Pemkot Bandar Lampung, 2018)

Masyarakat sangat awam dan tidak memahami betapa Covid 19 ini berbahaya bagi kesehatan masyarakat. Masih sering ditemui anak-anak usia pra sekolah dan usia sekolah yang berinteraksi tanpa mengenakan masker. Bukan itu saja, bahkan kegiatan pesta, arisan, kumpul-lkumpul para orang tua, tetap dilakukan (Buana \& Riiksa, 2020). Di Bandar Lampung pada Bulan Mei beberapa orang telah tertular Covid 19 di Kota Bandar Lampung. Hal ini terus berjalan hingga masa lockdown memasuki Bulan Juni 2020 dan seterusnya (Lampung, n.d.)

Dengan latar belakang itu, maka melalui pengabdian masyarakat, Program Studi Manajemen Institut Informatika dan Bisnis Darmajaya tergerak untuk melakukan kegiatan sosialisasi berbahayanya virus Covid 19 ini sekaligus mengusahakan sarana dan prasarana pencegahan virus Covid 19, dan membagikan flyer, brosur, poster, masker, hand sanitizer, dan bak cuci tangan kepada masyarakat yang menjadi target utama dalam kegiatan ini.

Dari hasil pengamatan di lapangan, maka tim pengabdian masyarakat merumuskan masalah yang ada di lokasi, diantaranya :

a. Sejauh apa pemahaman masyarakat terhadap bahaya Covid 19 ?

b. Apakah tersedia sarana prasarana untuk membantu masyarakat memahami dan mencegah bahaya Covid 19?

c. Apakah jika dilakukan sosialisasi dan pemberian bantuan sarana prasarana dapat meningkatkan kesadartahuan masyarakat untuk menjaga diri dari Covid 19?

Dalam melakukan pengabdian ini maka berbagai tinjauan pustaka yang dipergunakan 
adalah

\section{a. Covid 19}

Penyakit Corona Virus Disease (Covid19) pertama kali muncul di daerah Wuhan di negara Cina. Penyebarannya cepat sekali, yaitu melalui kontak fisik melalui hidung, mulut, dan mata, dan berkembang di paru. Tanda-tanda seseorang terkena Covid-19 adalah suhu tubuh naik, demam, mati rasa, batuk, nyeri di tenggorokan, kepala pusing, susah bernafas jika virus corona sudah sampai paruparu(Sigurvinsdottir et al., 2020)

b. Pencegahan Covid-19

Disebabkan oleh wabah ini, Kementerian Kesehatan merilis aturan turunan guna merinci Peraturan Pemerintah (PP) Nomor 21 Tahun 2020. PP ini mengatur tentang Pembatasan Sosial Berskala Besar dalam Rangka Percepatan Penanganan Corona Virus Disease 2019 ( Covid-19). Dalam Peraturan Menteri Kesehatan Republik Indonesia Nomor 9 Tahun 2020 tentang PSBB dalam Rangka Penanganan Covid19. Cakupan PSBB diantaranya meliburkan sekolah , tempat kerja, fasilitas umum. Pengecualian dilakukan untuk supermarket, minimarket, pasar, toko, lokasi penjualan obat-obatan, dan peralatan medis. Tempat penyediaan kebutuhan pokok, kegiatan sosial dan budaya juga tidak diperkenankan tutup namun dilaksanakan dengan protokol kesehatan penuh, Dilakukan pula pelarangan kerumunan orang, pertemuan politik, olahraga, hiburan, akademik, dan
budaya.Pembatasan moda transportasi juga dilakukan dengan pengecualian transportasi penumpang umum atau pribadi.Namun dengan pembatasan jumlah penumpang dan menjaga jarak antar penumpang. Kegiatan lain terkait aspek pertahanan dan keamanan kecuali, kegiatan pertahanan dan keamanan dalam upaya menegakkan kedaulatan Negara, keutuhan wilayah, serta melindungi bangsa dari ancaman dan gangguan, serta dalam rangka mewujudkan keamanan dan ketertiban masyarakat umum(Yunus et al., 2020).

\section{c. Sosialisasi}

Dalam rangka memberikan pengetahuan mengenai cakupan Pembatasan Sosial Skala Besar (PSBB), maka dilakukan kegiatan sosialisasi kepada seluruh unsur masyarakat sehingga masyarakat memiliki pemahaman yang penting mengenai bagaimana bertindak dan berperilaku dalam menghadapi Covid-19 ini.Sosialisasi bagaimana menghadapi wabah Covid-19 dapat dilakukan oleh semua unsur dan lapisan masyarakat karena secara moral dan kaidah sosial ini adalah tanggungjawab kita bersama. Pemahaman harus diberikan pula kepada masyarakat bahwa perang melahan wabah Covid 19 ini bukan hanya tugas dan tanggung jawab pemerintah, namun merupakan tanggung jawab bersama. Dari mulai unsur pemerintah, tenaga kesehatan, pihak swasta, tokoh masyarakat dan pemuka agama, 
masyarakat awam, media massa dan aparat penegak hukum bersama-sama melawan Covid-19. Peran seluruh lapisan masyarakat sangat dibutuhkan untuk melawan covid 19, sebab hanya masyarakat yang dapat memutuskan mata rantai penyebaran virus Corona ini. memutus mata rantai dengan cara melakukan sosial lockdown, distancing (menjaga jarak), karantina wilayah. Tak kalah penting adalah tetap menjaga kesehatan dan kebersihan lingkungan(Hartati \& Syafrida, 2020).

d. Sarana Prasana Mencegah Covid 19

Untuk melakukan pecegahan Covid-19 ini, maka diperlukan sarana prasarana untuk menggugah masyarakat agar semakin sadar untuk hidup sehat. Salah satu sarana dan prasarana yang diberikan adalah brosur dan flyer yang dibagikan kepada sleuruh masyarakat.Brosur ini berisi informasi tentang Covid-19 sehingga masyarakat semakin paham, isi brosur ini juga menjelaskan bagaimana menggunakan alat pelindung diri (APD). Pemberian APD juga dilakukan, seperti masker, hand sanitizer, sabun cuci tangan, penyediaan tempat cuci tangan di beberapa tempat vital, seperti dekat fasilitas kesehatan, tempat umum, dll.

Kegiatan pengabdian masyarakat yang difokuskan di Kecamatan Kemiling Kota Bandar Lampung ini bertujuan untuk memberikan informasi yang mudah diakses oleh masyarakat awam, sehingga masyarakat terpapar informasi yang tepat dan jelas mengenai Covid 19 ini sehingga bisa melakukan pencegahan secara mandiri di mulai dari diri sendiri, keluarga, tetangga, dan lingkungan sekitarnya. Secara lengkap, tujuan tersebut adalah untuk :

a. Mengetahui sejauh apa masyarakat pahami mengenai bahaya Covid 19

b. Masyarakat mendapatkan sarana prasarana yang membantu meningkatkan pemahaman mereka dalam mencegah Covid 19.

c. Masyarakat makin memahami bahaya Covi 19 sehingga bisa menjaga diri dan lingkungan dengan baik.

\section{METODE PELAKSANAAN KEGIATAN}

Masalah yang akan dipecahkan dalam kegiatan pengabdian kepada masyarakar ini adalah untuk memberikan pemahaman kepada masyarakat dalam mengenali penyakit dan wabah Covid-19. Pemahaman ini dilakukan dengan memberikan sosialisasi kepada masyarakat dengan mendatangi masyarakat door to door, pengumpulan beberapa lapis masyarakat secara terbatas, menyusun materi mengenai bahaya Covid-19 yang dituangkan dalam bentuk brosur dan flyer untuk kemudian dibagikan kepada masyarakat. Penyediaan Alat Pelindung Diri (APD) juga dilakukan, seperti pembagian masker, menyediakan hand sanitizer, dan sabun cuci tangan. Di beberapa titik vital dan berpotensi ada kerumuman orang juga diberikan fasilitas tempat cuci tangan.

\section{HASIL DANPEMBAHASAN}

Penyakit Corona Virus Disease (Covid19) yang muncul pertama kali WuhanCina 
penyebarannya sangat . Penyebaran terjadi melalui kontak fisik melalui hidung, mulut, dan mata, dan berkembang di paru. Tandatanda seseorang terkena Covid-19 adalah suhu tubuh naik, demam, mati rasa, batuk, nyeri di tenggorokan, kepala pusing, susah bernafas jika virus corona sudah sampai paru-paru.Kementerian Kesehatan merilis aturan turunan guna merinci Peraturan Pemerintah (PP) Nomor 21 Tahun 2020. PP ini mengatur tentang Pembatasan Sosial Berskala Besar dalam Rangka Percepatan Penanganan Corona Virus Disease 2019 ( Covid-19). Dalam Peraturan Menteri Kesehatan Republik Indonesia Nomor 9 Tahun 2020 tentang PSBB dalam Rangka Penanganan Covid-19. Cakupan PSBB diantaranya meliburkan sekolah, tempat kerja dan fasilitas umum. Namun untuk memenuhi kebutuhan ekonomi masyarakat, pusat ekonomi seperti pasar, supermarket, toko, pusat penjualan obat-obatan, dan peralatan medis tetap dibuka dengan menerapkan protokol kesehatan penuh. Atas dasar ini lah maka kegiatan pengabdian masyarakat ini dilakukan.Yakni bertujuan untuk memberikan sosialisasi dan himbauan kepada masyarakat untuk menghadapi wabah Covid-19 ini dengan menerapkan kehatihatian dalam bersosialisasi dengan anggota masyarakat lainnya [2].

Sosialisasi memberikan manfaat yang jelas yakni tercapainya peningkatan pengetahuan dari masyarakat tentang bahaya Covid-19 dan bagaimana menghindari diri pribadi, keluarga, dan seluruh masyarakat dari wabah Covi-19 ini. Para diri pribadi tumbuh menjadi kumpulan masyarakat yang tidak takut berlebihan terhadap Covid-19 namun memiliki kemampuan untuk mengenali apa dan bagaimana Covid-19 menginfeksi manusia dan sekaligus mengetahui dengan jelas bagaimana melindungi diri dari virus ini.

Penyediaan Alat Pengaman Diri (APD) seperti masker juga memberikan kesadaranan tinggi masyarakat untuk senantiasa mengenakan masker jika berada di kerumunan yang tidak terhindarkan (Yucesahin, 2020). Seperti di pasar, pusat pertokoan, sarana kesehatan, dan lainnya.Begitu juga jika ada anggota keluarga yang memiliki gejala sakit batuk, flu, demam, masyarakat dapat membantu untuk mengingatkan dalam mengenakan masker. Penyediaan hand sanitizer, sabun cuci tangan, dan wadah air untuk cuci tangan, dalam kegiatan yang melibatkan lebih dari 10 orang atau di tempat yang berpotensi munculnya kerumunan warga juga telah memberikan kesadaran bagi masyarakat untuk lebih menjaga diri dari Covid-19 ini [3].

Hasil yang telah dicapai dalam proses kegiatan ini adalah :

1. Tahap Persiapan

Tahap persiapan dilakukan dengan cara melakukan kunjungan ke aparat desa dan kelurahan dan mengumpulkan informasi sejauh mana pemahaman masyarakat tentang Covid-19 ini. dari hasil wawancara dengan para aparat desa 
didapatkan pemahaman sebagai berikut :

a. Masyarakat masih sangat awam dengan adanya wabah Covid-19.

b. Beberapa anggota masyarakat cenderung takut berlebihan dengan adanya Covid ini namun di sisi lain masih ada anggota masyarakat lainnya yang sangat menganggap remeh Covid-19 ini.

c. Belum tersedia informasi yang cukup tentang bahaya Covid-19 ini sehingga masyarakat tidak paham secara detail apayang harus dilakukan untuk menghadapi Covid-19 ini.

d. Belum tersedia APD yang memadai untuk membantu masyarakat menjaga diri dari bahaya Covid-19 ini.

2. Tahap Sosialisasi

Tahap selanjutnya yaitu kegiatan sosialisasi. Kegiatan sosialisasi di lakukan dengan cara mengumpulkan anggota masyarakat dalam jumlah terbatas. Paling banyak hanya 10 hingga 15 orang saja sehingga tidak berpotensi untuk terjadinya perkumpulan masyarakat yang beresiko penularan Covid-19. Anggota masyarakat yang dikumpulkan merupakan perwakilan dari anggota masyarakat yang memiliki pengaruh lebih. Seperti ketua pengajian, koordinator arisan, Ibu-Ibu PKK, tokoh masyarakat, ustadz, dll. Sosialisasi ini bertujuan untuk menjelaskan bahayanya wabah Covid-19 dan menjelaskan hal-hal apa saja yang dapat dilakukan untuk melakukan pencegahan terhadap wabah ini. Adapun sosialisasi dilengkapi dengan a. Brosur dan flyer yang berisi pengetahuan detail mengenai wabah Covid-19

b. Spanduk yang berisi ajakan warga untuk menjaga kesehatan dan mengenakan masker

c. Ceramah singkat untuk memberikan pengetahuan tentang Covid-19.

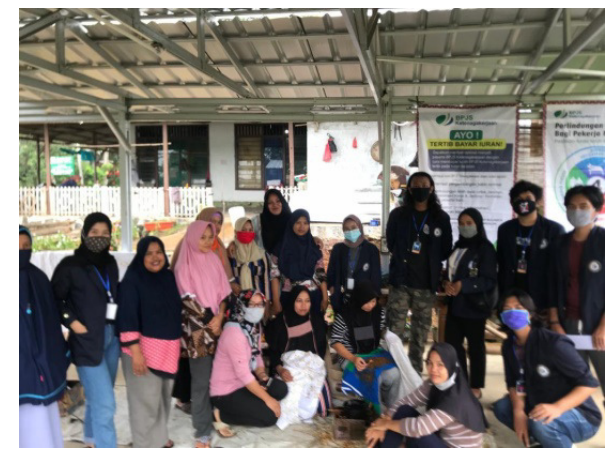

Gambar 1. Kegiatan sosialisasi

3. Tahap Pembagian Alat Pengaman Diri (APD)

Tahap selanjutnya setelah diadakan sosialisasi maka disalurkannya APD kepada masyarakat untuk makin meningkatkan kesadartahuan mereka dalam menghadapi wabah Covid-19 ini. APD yang disalurkan antara lain :

a. Masker

Pembagian masker sebagai salah satu bentuk kepedulian bagi masyarakat untuk menanggulangi Covid-19. Masker yang dibagikan kepada masyarakat adalah masker kain non-medis yang dapat dipergunakan berulang dan dapat dicuci . Pembagian masker ini utamanya ditujukan untuk masyarakat yang sangat membutuhkan namun masih sulit untuk mendapatkan masker. Padahal masker sangat diperlukan melakukan untuk 
beraktivitas di luar rumah. Dengan adanya pembagian masker ini diharapkan dapat menumbuhkan kesadaran masyarakat akan pentingnya penggunaan masker sebab masker diperlukan sebagai salah satu alat pelindung diri dan dapat mendukung pemerintah untuk menekan angka penyebaran Covid-19.

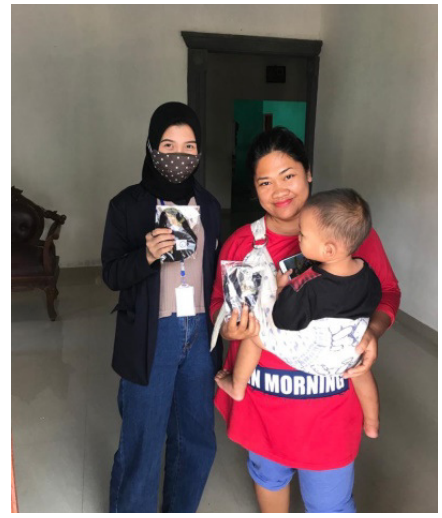

Gambar 2. Pembagian masker

b. Hand Sanitizer

Pembagian hand sanitizer dibagikan dengan beberapa cara diantaranya dilakukan secara langsung pada saat tim pengabdian masyarakat mengumpulkan beberapa elemen masyarakat pada saat melakukan sosialisasi. Sebanyak 20 liter yang dikemas pada botol sprayer ukuran kecil sehingga bisa dibagikan secara merata kepada anggota masyarakat lainnya. Lalu selama masih berada dalam jadwal kegiatan pengabdian masyarakat, tim juga menerima isi ulang jika anggota masyarakat ada yang meminta dengan membawa botol sprayer kosong.

c. Bak Kecil Wadah Air

Pemberian bak kecil untuk wadah air difokuskan di pusat-pusat belanja, seperti pasar, toko kelontong, pusat kegiatan masyarakat, dan tempat lain yang berpotensi munculnya kerumunan masyarakat. Pemberian wadah bak ini dibarengi dengan pemberian sabun antiseptic agar masyarakat memiliki kebiasaan baru dalam menjaga kebersihan yakni senantiasa mencuci tangan dengan sabun

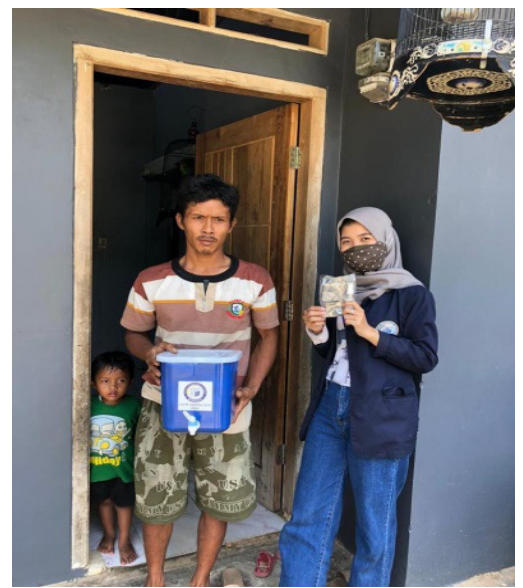

Gambar 3. Pembagian sabun cuci tangan dan bak ember cuci tangan

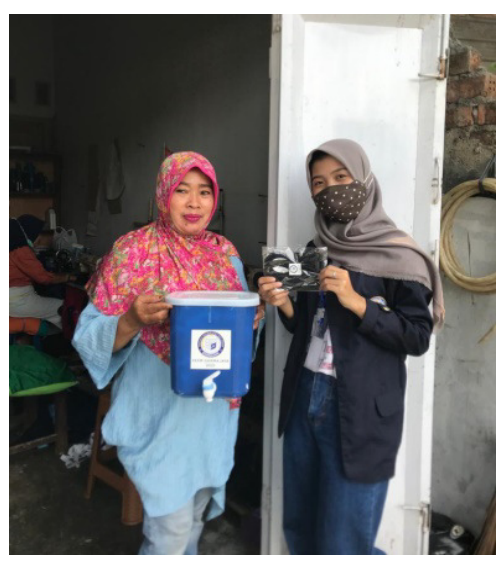

Foto Pembagian hand sanitizer dan bak ember cuci tangan

\section{KESIMPULAN}

Setelah diadakan sosialisasi mengenai bahaya wabah Covid-19 ini maka telah muncul kesadaran dari masyarakat mengenai wabah ini. masyarakat jadi memahami dengan lebih detail dan lebih baik mengenai gejala-gejala yang ditunjukkan oleh penyakit ini. Masyarakat juga memahami bagaimana 
meningkatkan kesadaran diri, keluarga, dan lapisan masyarakat untuk menjaga dari kemungkinan terpaparnya mereka dari Covid-19. Tumbuh pula kesadaran dari mereka untuk mengenakan APD yakni masker terutama di tempat-tempat yang berpotensi ada kerumunan massa. Kebiasaan sehat lainnya yang tumbuh dan berkembang adalah kesadaran untuk mencuci tangan menggunakan air dan sabun jika sehabis melakukan kontak dengan anggota masyarakat lainnya atau ketika pulang dari bepergian yang ada kontak fisiknya seperti pasar, toko, dan lainnya.Jika tidak menemukan air dan sabun cuci tangan maka telah tumbuh pula kesadaran untuk menggunakan hand sanitizer sebagai bentuk pencegahan terpapar virus Covid-19 ini.

\section{SARAN}

Wabah Covid-19 ini diprediksi masih akan terus terjadi hingga satu atau dua tahun mendatang. Oleh sebab itu sangat disarankan untuk semua pihak dapat bekerja sama dan memberikan langkah nyata yang terbaik agar masyarakat paham akan arti pentingnya menjaga kesehatan di era ini.

\section{UCAPAN TERIMAKASIH}

Terimakasih setinggi-tingginya kami ucapkan kepada Institut Informatika dan Bisnis (IIB) Darmajaya yang telah mendukung penuh kegiatan pengabdian kepada masyarakat dalam kegiatan akademik Praktek Kerja Pengabdian Masyarakat (PKPM) yang dilakukan bersama-sama antara dosen, mahasiswa, dan anggota masyarakat. Terimakasih juga disampaikan kepada seluruh aparat Desa Pinang Jaya kecamatan Kemiling Kota Bandar Lampung yang telah membantu terselenggaranya kegiatan pengabdian kepada masyarakat ini.

\section{REFERENSI}

Buana, B., \& Riiksa, D. (2020). Analisis Perilaku Masyarakat Indonesia dalam Menghadapi Pandemi Virus Corona (Covid-19) dan Kiat Menjaga Kesejahteraan Jiwa. Jurnal Sosial Dan Budaya Syar-I, 7(3).

Hartati, R., \& Syafrida, S. (2020). Bersama Melawan Virus Covid-19 di Indonesia. SALAM: Jurnal Sosial Dan Budaya Syar-I, 7(6).

Lampung, I. C. (n.d.). Website Informasi Covid 19 Pemerintah Provinsi

Lampung. Retrieved February 15, 2021, from https://covid19.lampungprov.go.id/

Pemkot Bandar Lampung, P. K. (2018). Kecamatan Kemiling Kota Bandar Lampung.

https://keckemiling.bandarlampungkota. go.id/

Sigurvinsdottir, R., Thorisdottir, I. E., \& Gylfason, H. F. (2020). The Impact of COVID-19 on Mental Health: The Role of Locus on Control and Internet Use. International Journal of Environmental Research and Public Health, 17(19), 6985.

https://doi.org/10.3390/ijerph17196985

Yucesahin, M. (2020). Coronavirus and Migration: Analysis of Human Mobility and the Spread of COVID-19. Migration Letters, 17(2), 379-398.

Yunus, N., Rezki, R., \& Annisa, A. (2020). Kebijakan Pemberlakuan Lock Down Sebagai Antisipasi Penyebaran Corona Virus Covid-19. SALAM: Jurnal Sosial Dan Budaya Syar-I, 7(3). 